\title{
Neurological disorders in adult celiac disease
}

\author{
Hugh J Freeman MD CM FRCPC FACP
}

HJ Freeman. Neurological disorders in adult celiac disease. Can J Gastroenterol 2008;22(11):909-911.

Celiac disease may initially present as a neurological disorder. Alternatively, celiac disease may be complicated by neurological changes. With impaired nutrient absorption, different deficiency syndromes may occur and these may be manifested clinically with neurological changes. However, in patients with deficiency syndromes, extensive involvement of the small intestine with celiac disease is often evident. There are a number of reports of celiac disease associated with neuropathy, ataxia, dementia and seizure disorder. In these reports, there is no clear relationship with nutrient deficiency and a precise mechanism for the neurological changes has not been defined. A small number of patients have been reported to have responded to vitamin $\mathrm{E}$ administration, but most do not. In some, gluten antibodies have also been described, especially in those with ataxia, but a consistent response to a gluten-free diet has not been defined. Screening for celiac disease should be considered in patients with unexplained neurological disorders, including ataxia and dementia. Further studies are needed, however, to determine if a gluten-free diet will lead to improvement in the associated neurological disorder.

\section{Les troubles neurologiques en cas de maladie cœliaque chez les adultes}

La maladie cœliaque peut constituer d'abord un trouble neurologique. Elle peut aussi être compliquée par des modifications neurologiques. En raison de la défaillance de l'absorption des nutriments, divers syndromes déficitaires peuvent survenir et se manifester cliniquement par des modifications neurologiques. Cependant, chez les patients ayant des syndromes déficitaires, une atteinte importante de l'intestin grêle touché par la maladie coliaque est souvent évidente. Plusieurs comptes rendus associent la maladie cœliaque à une neuropathie, une ataxie, une démence ou des troubles convulsifs. Dans ces comptes rendus, il n'y a pas de relation claire avec la carence en nutriments, et on n'a pas défini de mécanisme précis de modifications neurologiques. Quelques patients ont réagi à l'administration de vitamine $\mathrm{E}$, mais la plupart n'y réagissent pas. Chez certains, on a également décrit des anticorps au gluten, surtout chez ceux présentant une ataxie, mais il n'existe pas de définition de réponse uniforme à un régime sans gluten. Il faudrait envisager de procéder à un test de dépistage de la maladie cœliaque chez les patients atteints de troubles neurologiques inexpliqués, y compris l'ataxie et la démence. D'autres études s'imposent, cependant, pour déterminer si un régime sans gluten favorisera une atténuation du trouble neurologique connexe.
Key Words: Ataxia; Celiac disease; Dementia; Epilepsy; Gluten-free diet; Neurological disorders; Neuropathy; Seizure disorders; Vitamin E to its recognition $(4,5)$. Some disorders may be the result of micronutrient malabsorption, particularly vitamins, while others may share an immune-mediated etiology or other pathogenesis that requires elucidation.

\section{VITAMIN DEFICIENCY SYNDROMES}

Some vitamin deficiency syndromes that cause neurological deficits are listed in Table 1 (6). These are uncommon, unless severe and extensive involvement of the small intestine is present as a result of celiac disease. Thiamine deficiency is rare, but may sometimes occur if there is concomitant alcohol abuse and dependency in addition to the celiac disease (especially if, for any reason, intravenous dextrose is administered alone). A disorder virtually identical to the Wernicke-Korsakoff syndrome with opthalmoplegia, ataxia and confusion may develop (7). Recognition may be difficult because the syndrome can occur alone and diagnostic delay may result in impaired short-term memory. Beri-beri may cause a sensory axonal neuropathy, usually characterized by burning feet, and often accompanied by cardiac failure (8).

Vitamin $B_{12}$ deficiency is generally uncommon in uncomplicated celiac disease. In most individuals, the principal absorptive site for vitamin $B_{12}$ is the distal small bowel, a site usually spared disorders may be the initial manifestation of celiac disease, leading 


\begin{tabular}{|c|c|}
\hline Vitamin & Associated neurological disorder(s) with deficiency \\
\hline $\mathrm{B}_{1}$ & $\begin{array}{l}\text { Neuropathy, ophthalmoplegia, dementia, cerebellar ataxia, } \\
\text { optic neuritis }\end{array}$ \\
\hline $\mathrm{B}_{6}$ & Neuropathy \\
\hline $\mathrm{B}_{12}$ & $\begin{array}{l}\text { Neuropathy, dementia, cerebellar ataxia, optic neuritis, } \\
\text { myelopathy }\end{array}$ \\
\hline $\mathrm{E}$ & $\begin{array}{l}\text { Neuropathy, ophthalmoplegia, cerebellar ataxia, } \\
\text { extrapyramidal disorders, myelopathy }\end{array}$ \\
\hline Niacin & $\begin{array}{l}\text { Neuropathy, dementia, cerebellar ataxia, extrapyramidal } \\
\text { disorders, myelopathy }\end{array}$ \\
\hline Riboflavin & Ophthalmoplegia \\
\hline
\end{tabular}

in celiac disease because involvement is usually limited to the proximal small intestine. Other possible reasons for vitamin $B_{12}$ deficiency may occur in adult celiac disease. Autoimmune gastritis with pernicious anemia may coexist with celiac disease and may be responsible. Alternatively, pancreatic exocrine insufficiency may occur in celiac disease (9) so that normal mechanisms (eg, pancreatic enzymatic hydrolysis of $\mathrm{R}$ factor) leading to presentation of luminal vitamin $B_{12}$ to ileal receptors for its intestinal uptake may be altered. Finally, bacterial overgrowth may occur in celiac disease, especially if there is a coexistent alteration in small intestinal motility. Neurological changes may also occur in vitamin $B_{12}$ deficiency without hematological abnormalities, including sensory neuropathy, usually in the upper limbs, myelopathy, optic nerve dysfunction and dementia $(6,10)$. Subacute combined degeneration may cause pyramidal signs with reduced dorsal column function and this may not be reversible with replacement therapy.

Vitamin E deficiency may cause a sensory neuropathy with loss of joint-position sense and a head tremor. These may be improved, in part, with vitamin E supplementation (11). Niacin deficiency is rare, but dementia may result (12). Ataxia and seizures have also been described with niacin deficiency (7)

\section{OTHER NEUROLOGICAL CHANGES IN CELIAC DISEASE}

Neuropathy, ataxia, seizure disorders and impaired cognitive function (or dementia) have most often been described. In some patients, vitamin deficiency has been hypothesized or a concomitant immune-mediated mechanism may be responsible. For most patients, however, the precise mechanism is unknown and requires elucidation. For many, the response in neurological changes to a gluten-free diet has either been poor or fails to occur.

\section{Neuropathy}

Up to $50 \%$ of celiac disease patients may develop peripheral neuropathy (13). Importantly, neuropathy may precede the diagnosis of biopsy-defined celiac disease (14), and should be considered especially if a symmetric distal form of sensory neuropathy is evident (14). Other neuropathic processes that can occur in celiac disease include a pure motor neuropathy, a form of mononeuritis multiplex, a Guillain-Barré-like syndrome and an autonomic neuropathy (1417). Electrophysiological studies, sural nerve or skin biopsies may be abnormal $(14,18,19)$ and autoantibodies to gangliosides may be detected (20). These autoantibodies may bind to Schwann cell surfaces, nodes of Ranvier and peripheral nerve axons (20). Some have suggested a positive effect of a gluten-free diet on the neuropathy (16); however, others have recorded continued symptoms or even progression of the neuropathy while maintaining a gluten-free diet
(21). In celiac disease with multifocal axonal polyneuropathy, intravenous immunoglobulin may be beneficial (19).

Neuropathy may also be associated with lymphoma, thus, complicating celiac disease. This may occur directly with lymphomatous involvement of nerves or indirectly as a paraneoplastic phenomenon, similar to other malignant disorders. Interestingly, in a case of a disseminated enteropathy-type $\mathrm{T}$ cell lymphoma, a cauda equina syndrome was reported (22).

\section{Ataxia}

In biopsy-defined celiac disease, gait ataxia occurs, often associated with neuropathy (23). In other individuals with ataxia, cerebellar involvement may occur $(24,25)$ with low vitamin E levels (26). In some, recognition of celiac disease may be preceded by cerebellar changes, but there are no clinical features of the ataxia that are distinctive for underlying adult celiac disease (27). In some ataxia studies (28), only serological tests were performed and celiac disease was not confirmed or biopsy-defined. Antigliadin antibodies have been noted in ataxia (28) and have also been noted in other genetically based neurodegenerative disorders (eg, spinocerebellar ataxia, Huntington's disease) $(29,30)$.

Some have postulated that antibodies to gliadin or a peptide sequence of gliadin are neurotoxic, particularly to the cerebellum. Occasionally, biopsy-defined celiac disease is present; however, most patients have no evidence of detectable intestinal disease. In these individuals, antigliadin antibodies may simply represent an epiphenomenon with no pathogenic significance (31). In some patients, supplementation with vitamin $\mathrm{E}$ has apparently been useful. In others, however, normal vitamin E levels have been defined and the gait ataxia syndrome has been hypothesized to be the result of a mechanism other than a nutrient deficiency. It has also been suggested (32) that ataxia may be the result of the toxic effects of gluten per se, the so-called 'gluten-ataxia' hypothesis. To date, however, restriction of gluten alone has not been clearly shown to be an effective treatment (33-35). Claims related to the effectiveness of intravenous immunoglobulin therapy have also appeared (36).

Of note, ataxia with a pancerebellar syndrome has been associated with $\mathrm{T}$ cell enteropathy and lymphomatous metastases to the cerebellum (37), suggesting that this should be kept in mind for patients with celiac-related enteropathies before attributing cerebellar findings to different vitamin or other nutritional deficiencies or an associated autoimmune mechanism.

\section{Seizure disorder}

Seizure disorder (ie, epilepsy) appears to be associated with celiac disease $(38,39)$, most often, but not exclusively, in pediatric celiac disease, rather than in adults. The effect of a glutenfree diet is not clear. Some studies (40) have reported better seizure control in children that resulted from a reduction in seizure-control medications.

A specific seizure disorder syndrome has been recorded in celiac disease with bilateral occipital calcification. This intriguing, but rare entity was first described in 1970 (41) and was later confirmed, particularly in reports from Italy $(42,43)$. The majority of patients had complex partial seizures referable to the occipital or temporal lobes; however, generalized seizures may also occur $(44,45)$. Calcification is generally bilateral and, pathologically, the calcifications consist of patchy pial angiomas, fibrosed veins and large microcalcifications containing calcium and silica (46).

\section{Impaired cognitive function}

Dementia may occur in celiac disease, particularly in the form of memory impairment (47). In most patients, a gluten-free diet does not appear to result in an improvement of neurological disability (47). In a case series (48), the most common presenting 
neurological features were amnesia, acalculia, confusion and personality changes. In subjects with a deficiency of folic acid, vitamin $B_{12}$ or vitamin $E$, subsequent supplementation had no effect in reversing the neurological findings. However, some patients appeared to stabilize after removal of dietary gluten. Pathology studies (48) demonstrated a nonspecific gliosis. Interestingly, in a study of seven elderly celiac patients diagnosed after 60 years of age, cognitive decline attributed to Alzheimer's dementia was evident in three cases and, in one case, neurological changes were ameliorated after initiation of a gluten-free diet (49).

\section{Other neurological disorders}

Other neurological disorders have been encountered in single case reports or case series. However, further studies are needed to determine if these disorders are directly related to adult celiac disease or represent coincidental occurrences.

\section{CONCLUSION}

Celiac disease may be initially defined after presentation with a neurological disorder. Screening for celiac disease should be considered, especially if a definitive cause for the neurological disorder is not obvious. Further studies are also needed to determine if neurological changes that have been attributed to the so-called 'gluten-sensitivity' in the absence of overt intestinal disease (50) can be truly reversed with a gluten-free diet.

\section{REFERENCES}

1. Freeman HJ. Pearls and pitfalls in the diagnosis of adult celiac disease. Can J Gastroenterol 2008;22:273-80.

2. Dube C, Rostom A, Sy R, et al. The prevalence of celiac disease in averagerisk and at-risk Western European populations: A systematic review. Gastroenterology 2005;128:S57-67.

3. Freeman HJ. Clinical spectrum of biopsy-defined celiac disease in the elderly. Can J Gastroenterology 1995;9:42-6.

4. Luostarinen L, Pirttila T, Collin P. Celiac disease presenting with neurological disorders. Eur Neurol 1999;42:132-5.

5. Zelnik N, Pacht A, Obeid R, Lerner A. Range of neurologic disorders in patients with celiac disease. Pediatrics 2004;113:1672-6.

6. Cooke WT. The neurological manifestations of malabsorption. Postgrad Med J 1978;54:760-2.

7. Robinson K. Wernicke's encephalopathy. Emerg Nurse 2003;1:30-3.

8. Jeyajumar D. Beri-beri in immigrant workers-a report of three cases. Med J Malaysia 1994;49:187-91.

9. Freeman HJ. Pancreatic endocrine and exocrine changes in celiac disease. World J Gastroenterol 2007;13:6344-6.

10. Reynolds EH. Neurological aspects of folate and vitamin B12 metabolism. Clin Hematol 1976;5:661-96.

11. Hammans SR, Kennedy CR. Ataxia with isolated vitamin E deficiency presenting as mutation negative Friedreich's ataxia. J Neurol Neurosurg Psychiatry 1998;64:368-70.

12. van der Horst-Schrivers AN, Wymenga AN, Links TP, Willemse PH, Kema IP, de Vries EG. Complications of midgut carcinoid tumors and carcinoid syndrome. Neuroendocrinology 2004;80(suppl 1):28-32.

13. Cicarelli G, Della Rocca G, Amboni M, et al. Clinical and neurological abnormalities in adult celiac disease. Neurol Sci 2003;24:311-7.

14. Chin RL, Sander HW, Brannagan TH, et al. Celiac neuropathy. Neurology 2003;60:1581-5.

15. Banerji NK, Hurwitz LJ. Neurological manifestations in adult steatorrhea (probably gluten enteropathy). J Neurol Sci 1971;14:125-41.

16. Kaplan JG, Pack D, Horoupian D, De Souza T, Brin M, Schaumburg H. Distal axonopathy associated with chronic gluten enteropathy: A treatable disorder. Neurology 1988;38:642-5.

17. Usai P, Usai Satta P, Lai M, et al. Autonomic dysfunction and upper digestive functional disorders in untreated adult celiac disease. Eur J Clin Invest 1997;27:1009-15.

18. Brannagan TH, Hays AP, Chin SS, et al. Small-fiber neuropathy/neuronopathy associated with celiac disease. Skin biopsy findings. Arch Neurol 2005;62:1574-8.

19. Chin RL, Tseng VG, Green PH, Sander HW, Brannagan TH, Latov N. Multifocal axonal polyneuropathy in celiac disease. Neurology 2006;66:1923-5.

20. Alaedini A, Green PH, Sander HW, et al. Ganglioside reactive antibodies in the neuropathy associated with celiac disease. J Neuroimmunol 2002;127:145-8.

21. Luostarinen L, Himanen SL, Luostarinen M, Collin P, Pirttila T. Neuromuscular and sensory disturbances in patients with well treated celiac disease. J Neurol Neurosurg Psychiatry 2003;74:490-4.

22. Doran M, Du Plessis DG, Larner AJ. Disseminated enteropathy-type-T-cell lymphoma: Cauda equina syndrome complicating celiac disease. Clin Neurol Neurosurg 2005;107:517-20.

23. Cooke W, Smith W. Neurological disorders associated with adult celiac disease. Brain 1966;89:683-722.

24. Finelli PF, McEntee WJ, Ambler M, Kestenbaum D. Adult celiac disease presenting as cerebellar syndrome. Neurology 1980;30:245-9.

25. Kristoferitsch W, Pointner H. Progressive cerebellar syndrome in adult celiac disease. J Neurol 1987;234:116-8.

26. Mauro A, Orsi L, Mortara P, Costa P, Schiffer D. Cerebellar syndrome in adult celiac disease with vitamin E deficiency. Acta Neurol Scand 1991;84:167-70.

27. Pellecchia MT, Scala R, Filla A, De Michele G, Ciacci C, Barone P. Idiopathic cerebellar ataxia associated with celiac disease: Lack of distinctive neurological features. J Neurol Neurosurg Psychiatry 1999;66:32-5.

28. Hadjivassiliou M, Gibson A, Davies-Jones GA, Lobo AJ, Stephenson TJ, Milford-Ward A. Does cryptic gluten sensitivity play a part in neurological illness? Lancet 1996;347:369-71.

29. Bushara KO, Goebel SU, Shill H, Goldfarb LG, Hallett M. Gluten sensitivity in sporadic and hereditary cerebellar ataxia. Ann Neurol 2001;49:540-3.

30. Bushara $\mathrm{KO}$, Nance M, Gomez CM. Antigliadin antibodies in Huntington's disease. Neurology 2004;62:132-3.

31. Dick DJ, Abraham D, Falkous G, Hishon S. Cerebellar ataxia in celiac disease - no evidence for a humoral etiology. Postgrad Med J 1995;71:186.

32. Hadjivassiliou M, Boscolo S, Davies-Jones GA, et al. The humoral response in the pathogenesis of gluten ataxia. Neurology 2002;58:1221-6.

33. Pellecchia MT, Scala R, Perretti A, et al. Cerebellar ataxia associated with subclinical celiac disease responding to a gluten-free diet. Neurology 1999;53:1606-8.

34. Bushara $\mathrm{KO}$, Shill $\mathrm{H}$, Hallett M. Open label trial of gluten-free diet in sporadic and hereditary cerebellar ataxia with gluten sensitivity. Mov Disord 2002;17:S325 (Abst)

35. Hadjivassiliou M, Davies-Jones GA, Sanders DS, Grunewald RA. Dietary treatment of gluten ataxia. J Neurol Neurosurg Psychiatry 2003;74:1221-4.

36. Burk K, Melms A, Schulz JB, Dichgans J. Effectiveness of intravenous immunoglobulin therapy in cerebellar ataxia associated with gluten sensitivity. Ann Neurol 2001;50:827-8.

37. Shams PN, Waldman A, Dogan A, MacKenzie JM, Plant GT. Ataxia in the setting of complicated enteropathy: Double jeopardy. J Neurol Neurosurg Psychiatry 2002;72:527-9.

38. Chapman RW, Laidlow JM, Colin-Jones D, Eade OE, Smith CL. Increased prevalence of epilepsy in celiac disease. BMJ 1978;2:250-1.

39. Cronin CC, Jackson LM, Feighery, et al. Celiac disease and epilepsy. QJM 1998;91:303-8.

40. Pratesi R, Modelli IC, Martins RC, Almeida PL, Gandolfi L. Celiac disease and epilepsy: Favorable outcome in a child with difficult to control seizures. Acta Neurol Scand 2003;108:290-3.

41. Visakorpi J, Kuitunen P, Pelkonen P. Intestinal malabsorption: A clinical study of 22 children over 2 years of age. Acta Pediatr Scand 1970;59:273-80.

42. Molteni N, Bardella MT, Baldassarri AR, Bianchi PA. Celiac disease associated with epilepsy and intracranial calcifications: Report of two patients. Am J Gastroenterol 1988;83:992-4.

43. Gobbi G, Bouquet F, Greco L, et al. Celiac disease, epilepsy, and cerebral calcifications. The Italian Working Group on Celiac Disease and Epilepsy. Lancet 1992;340:439-43.

44. Crosato F, Senter S. Cerebral occipital calcifications in celiac disease. Neuropediatrics 1992;23:214-7.

45. Arroyo HA, De Rosa S, Ruggieri V, de Davila MT, Fejerman N. Epilepsy, occipital calcifications, and oligosymptomatic celiac disease in childhood. J Child Neurol 2002;17:800-6.

46. Toti P, Balestri P, Cano M, et al. Celiac disease with cerebral calcium and silica deposits: X-ray spectroscopic findings, an autopsy study. Neurology 1996;46:1088-92.

47. Collin P, Pirttila T, Nurmikko T, Somer H, Erila T, Keyrilainen O. Celiac disease, brain atrophy, and dementia. Neurology 1991;41:372-5.

48. Hu WT, Murray JA, Greenaway MC, Parisi JE, Josephs KA. Cognitive impairment and celiac disease. Arch Neurol 2006;63:1440-6.

49. Lurie Y, Landau DA, Pfeffer J, Oren R. Celiac disease diagnosed in the elderly. J Clin Gastroenterol 2008;42:59-61.

50. Hadjivassiliou M, Grunewald R, Sharrack B, et al. Gluten ataxia in perspective: Epidemiology, genetic susceptibility and clinical characteristics. Brain 2003;126(Pt 3):685-91. 


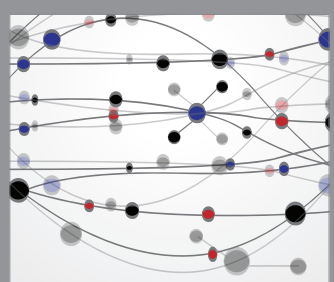

The Scientific World Journal
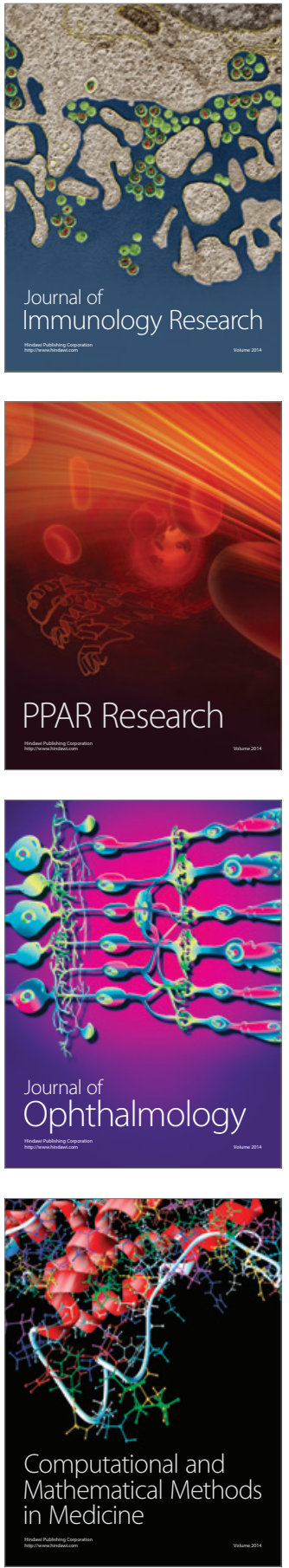

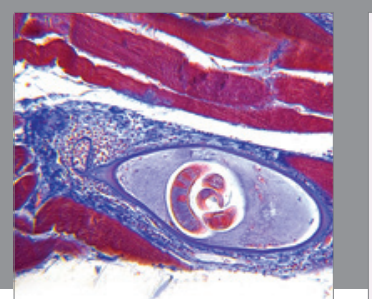

Gastroenterology Research and Practice

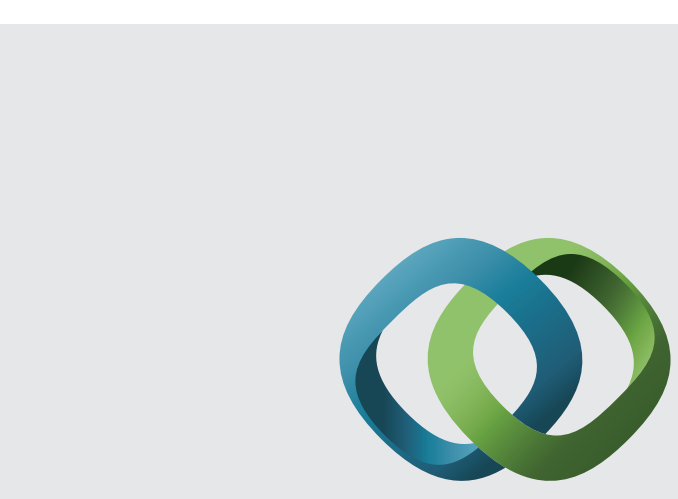

\section{Hindawi}

Submit your manuscripts at

http://www.hindawi.com
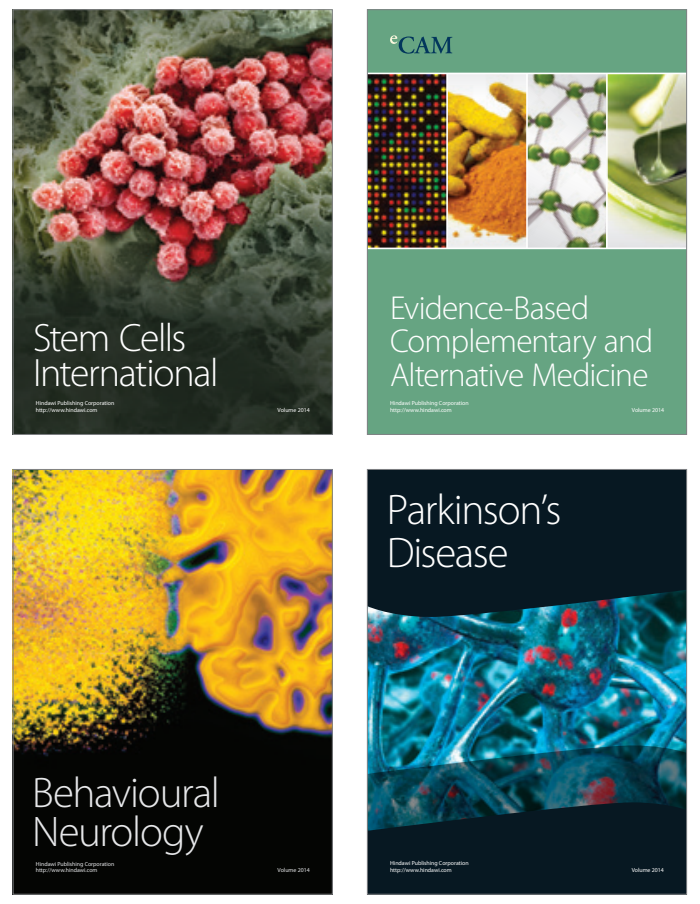
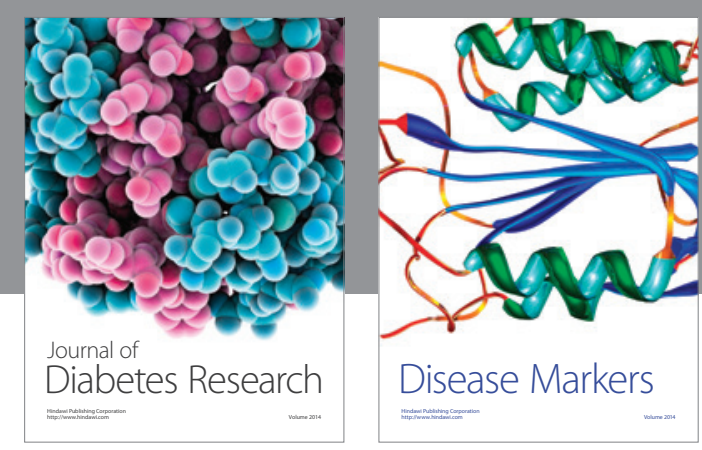

Disease Markers
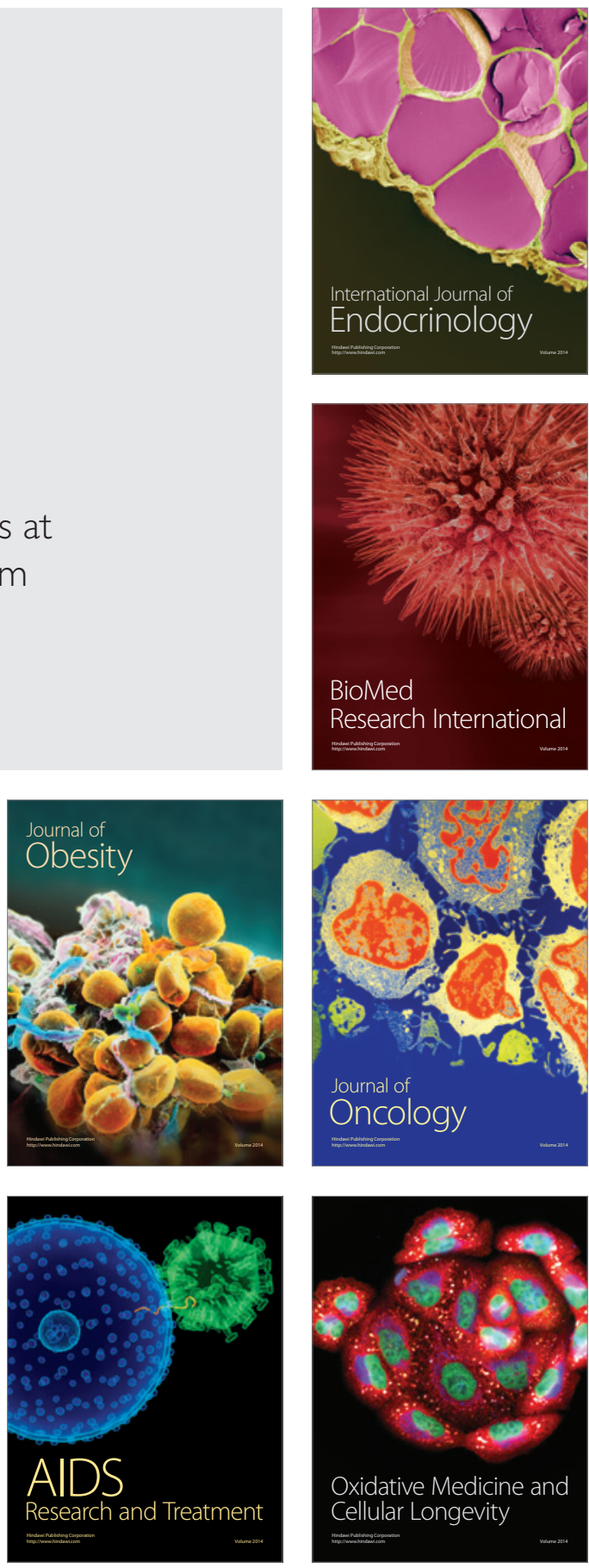